GRYNOVA M., ZHDANOVA-NEDILKO O.

Poltava V. G. Korolenko national pedagogical University, Ukraine

\title{
PREPARING THE HEAD OF THE NEW UKRAINIAN SCHOOL FOR PARTNERSHIP WITH THE EDUCATIONAL ENTITIES
}

The article deals with problems related to several important aspects of pedagogical innovation in modern Ukraine. The requirements for the head of the New Ukrainian School as an integrative figure in the context of the educational environment, the organization of his relations with students, teachers, parents of students, representatives of local communities are analyzed. The specifics of partnership are discussed as a means of establishing constructive contacts between subjects interested in a successful educational outcome.

It is substantiated that the professional training of the head of the New Ukrainian School should include two interrelated areas: content-technological, which includes mastering the above components of managerial training as the theoretical basis of his activity, and personal-activity, which allows to form a sufficiently flexible and at the same time conceptual individual system of administrative interaction with the subjects of the educational environment.

The high school's ability to form a future education manager's ability to engage in this interaction is being explored. It initiates the expansion of forms and methods of interaction between higher and secondary schools, which are able to accumulate their opportunities for early immersion of the future manager into the latter's educational environment in order to develop systemic managerial experience and to develop the capacity for effective management communication on the principles.

Keywords: New Ukrainian school; manager, educational environment; territorial community; parent community; partnership; higher education; vocational training; quasi-professional activity

Стаття надійшла до редакції 17.03. 2019 р.

УДК 378.091.3:373.5.011.3-051

DOI: https://doi.org/10.33989/2075-146x.2019.23.183190

НАТАЛІЯ ГУЗІЙ

ORCID ID 0000-0002-9158-9791

Національний педагогічний університет імені М.П.Драгоманова, м. Київ

\section{IМІТАЦІЙНО-СИТУАЦІЙНЕ НАВЧАННЯ У СИСТЕМІ КОНТЕКСНО ЗОРІЕНТОВАНОӤ ПІДГОТОВКИ МАЙБУТНІХ ПЕДАГОГІВ ДО ПРОФЕСІЙНОЇ ТВОРЧОСТІ ТА МАЙСТЕРНОСТІ}

\begin{abstract}
У статті представлено результати наукової рефлексії евристичних можливостей імітаційно-ситуаційного навчання у системі контекстно зорієнтованої підготовки майбутніх педагогів до професійної творчості та майстерності, а також висвітлено експериментальний досвід його використання при вивченні майбутніми педагогами навчальних дисциплін з основ педагогічної творчості та майстерності.
\end{abstract}

Ключові слова: контекстне навчання; імітаційно-ситуаційне навчання; дидаскалогічна освіта; педагогічна майстерність; педагогічна творчість

Актуальність дослідження. Розв'язання сучасних завдань державної освітньої політики, реалізація концептуальних засад Нової української школи зумовлюють пошук дієвих шляхів подальшого розвитку теорії та методики професійно-педагогічної підготовки освітянських кадрів, здатних досягти вершин професійної творчості та майстерності як найбільш визначних маркерів високопродуктивної педагогічної праці. Це вимагає подальшої наукової рефлексії професійного потенціалу однойменних навчальних дисциплін з основ педагогічної творчості та майстерності у збагаченні особистісних аспектів змісту педагогічної освіти та евристичних можливостей методичного арсеналу їх викладання, зокрема контекстного типу навчання студентів та одного 3 методів його реалізації - імітаційно-ситуаційного навчання.

Аналіз публікацій і досліджень. Фундаментальні дослідження теорії та методики професійно-педагогічної підготовки освітянських кадрів розкриваються у працях О.А.Абдулліної, О.А.Дубасенюк, Л.В.Кондрашової, О.Г.Мороза, В.О.Сластьоніна та ін., підготовки до професійної творчості та майстерності майбутніх педагогів - у науково-методичних розвідках Є.С.Барбіної, І.А. Зязюна, Н.В. Кічук, Н.В. Кузьміної М.О. Лазарєва, В.А.Семиченко, С.О. Сисоєвої, Р.П. Скульського, Н.М. Тарасевич, та ін. Мета-технологія контекстного навчання у вищій школі запропонована А.О. Вербицьким, а ії творче використання у різних видах вищої освіти представлено в роботах Н.В. Борисової, П.М. Гусака, О.А. Дубасенюк, В.А. Семиченко, М.Г. Чобітько та ін. Імітаційно-ситуаційне навчання майбутніх педагогів у його різноманітних проекціях презентовано у публікаціях Є.М. Глубокової, О.В.Матвієнко, Л.О.Мільто, Г.В. Нікішиної, В.Л. Омельяненка, М.В. Даниленко, Л.І. Даниленко, Л.В. Кондрашової, Л.І. Рувінського, Л.Шульман та ін. Проте, екстраполяція методів імітаційно-ситуаційного 
навчання у контексно зорієнтовану підготовку майбутніх педагогів до професійної творчості та майстерності у процесі їх дидаскалогічної освіти не знайшла ще достатньо повного й цілісного науково-методичного вирішення.

Мета дослідження. Мета статті полягає у науковій рефлексії евристичних можливостей імітаційноситуаційного навчання у системі контекстно зорієнтованої підготовки майбутніх педагогів до професійної творчості та майстерності, а також презентації експериментального досвіду його використання при вивченні студентами бакалаврату навчальних дисциплін з основ педагогічної творчості та майстерності.

Виклад основного матеріалу дослідження. Підготовка майбутнього педагога до професійної творчості та майстерності продовж останніх десятиліть залишається інноваційним вектором модернізації педагогічної освіти, будучи приналежною до ії некласичного типу. Пронизуючи різні напрями професійної підготовки освітянських кадрів - психологічної, дидактичної, методичної, управлінської тощо, цей іії сегмент найбільш концентровано представлений дидаскалогічною складовою, що об'єктивує сучасний рівень теоретичних й прикладних знань про специфіку, закономірності, механізми досягнення високої якості праці у педагогічній професії на рівні особистісних цінностей і смислів та розкриває наукову й технологічну базу успішної, продуктивної діяльності педагога-майстра, творця, професіонала у вигляді ії ідеальних моделей, оволодіння якими майбутніми педагогами уможливлює їх ефективне становлення як суб'єктів неперервного професійно-творчого зростання.

Феноменологія дидаскалогічної освіти (термін наш, Н.Г.), зумовлена насамперед тим, що в якості назв відповідних навчальних дисциплін використовуються різноманітні дефініції, які “символізують” та 3 різних позицій розкривають характеристики високої якості та продуктивності педагогічної праці й розвиненості особистості педагога. До них у вітчизняній освітній традиції передусім належать: педагогічна майстерність (І.А. Зязюн, Н.М. Тарасевич та ін.), педагогічна творчість (Н.В. Кічук, М.О. Лазарєв, С.О. Сисоєва, та ін.), педагогічна культура (Є.В. Бондаревська, В.М. Гриньова, І.Ф. Ісаєв та ін.), педагогічна техніка (В.М. Мидинкану, Ю.І. Турчанинова, В.П. Чихаєв та ін.), педагогічна деонтологія (Л.Л. Хоружа, К.М. Левітан) тощо. Їх відмінності, на думку Є.С.Барбіної та В.А. Семиченко (1996), полягають лише у номінальному виділенні різних системоутворювальних факторів, які характеризуються несуттєвими зміщеннями смислових аспектів та їх змістовим наповненням (Барбина, Семиченко с. 251). На наш погляд таке розмаїття дефініцій на позначення високоякісної педагогічної праці до того ж дозволяє утворити сучасний дидаскалогічний тезаурус, розширює й збагачує грані пізнання багатоаспектної педагогічної праці, відображає плюралізм та різновекторність розвитку дидаскалогічної думки, сприяє виробленню оригінальних професіографічних моделей успішного педагога. Це слід вважати суттєвими науковими здобутками дидаскалогічної думки, які створюють потужну теоретичну базу для ії дидактичних проекцій та використання у професійно-педагогічній підготовці студентів.

Базова відмінність дидаскалогічних навчальних дисциплін визначається також їх особливою предметністю та цільовими орієнтаціями - спрямованістю не лише на прирощення конкретних знань і умінь, а й на формування на цій основі особистісно-діяльнісних професійних новоутворень особистості майбутніх педагогів. Це досягається шляхом трансформації ідеальних модельних конструкцій певних дефініцій у дидактичну площину, за допомогою чого у свідомості й діяльності студентів спочатку моделюються, а потім відпрацьовуються методологічні та теоретичні, методичні та практичні аспекти відповідних еталонних зразків і стандартів педагогічної праці. До того ж процес опанування майбутніми педагогами змістом дидаскалогічних дисциплін слід вважати і дієвим засобом їх професійного виховання, вагомим фактором інтеграції професійної підготовки та забезпечення її цілісності.

Наведена аргументація дозволяє переконатися у некласичній природі дидаскалогічного знання, глибинній особистісно-професійній спрямованості змісту дидаскалогічних навчальних дисциплін, а також необхідності використання інноваційного, практико зорієнтованого індивідуально-творчого технологічного інструментарію для його опанування майбутніми педагогами, до якого було віднесено контекстний тип навчання студентів.

Контекстне (або знаково-контекстне) навчання в науково-педагогічній літературі визнається актуальним для організації будь-якого виду професійної освіти, у тому числі і педагогічної, оскільки дозволяє долати існуючий дисбаланс між теоретичною та практичною складовими підготовки фахівців, забезпечувати більш ефективну предметну та соціальну адаптацію студентів (Н.В. Борисова, П.М. Гусак, О.А. Дубасенюк, В.А. Семиченко, М.Г. Чобітько та ін.). Провідна ідея контекстного навчання полягає у тому, що навчальна інформація засвоюється студентом у контексті власної практичної дії, наближеної до предметного і соціального контекстів професійної праці як системи внутрішніх і зовнішніх умов діяльності та поведінки, яка впливає на сприйняття, розуміння й перетворення суб'єктом конкретної ситуації, надаючи їй професійного значення й індивідуального смислу. Це передбачає досить складний перехід діяльності майбутнього фахівця від учіння до професійної праці, що пов'язано із перетворенням знань $з$ предмета навчальної діяльності на засіб регуляції професійної діяльності, зміну провідного типу діяльності та соціальної позиції людини, а також трансформації ії мотивації - 3 навчальної на професійну.

Теоретичні позиції і відповідна педагогічна технологія контекстного навчання було запропоновано А.О. Вербицьким (1987). Сутність такого типу навчання автор вбачає у забезпеченні динамічної трансформації засвоєної навчальної інформації як певної знакової системи, що заміщує реальні предмети та явища на понятійному рівні, в особистісне знання, яке не лише адекватно відображає дійсність, а й перетворюється, на думку Т.С.Кошманової, у засіб здійснення та регуляції професійної діяльності, набуває особистісного смислу і відображає ставлення людини до праці (Кошманова, 2000, с. 22-24). У контекстному навчанні зміст діяльності студентів проектується не лише за логікою науки, а й за логікою майбутньої професії, що надає цілісності, системної організації та особистісної значущості засвоєним знанням і умінням. Крім цього, “задаються" специфічні просторово-часові координати розгортання змісту професійної діяльності, пї рольового інструментування та сценарного плану. Основною ж одиницею роботи викладача зі студентом стає не “порція інформації”, а проблемна ситуація професійної діяльності в усій ï предметній і соціальній неоднозначності та протиріччях. Навчальний матеріал у контекстному навчанні, як і в традиційному, є знаковою системою, але вона не просто “заміщує” 
професійну реальність, а й відтворює іï з необхідною повнотою для досягнення мети освіти і виховання. Тому змістом контекстного навчання виступає як предметна сторона майбутньої професійної діяльності, що визначається системою спеціальних завдань, моделей, ситуацій, так і соціальна сторона, що зумовлена специфічними формами спільної діяльності, тобто в процесі засвоєння предметного змісту навчання студент виробляє певну позицію у системі взаємодії учасників освітнього процесу, оволодіває існуючими нормами виробничих відносин (Вербицький, 1987, с. 33-34).

Моделювання та засвоєння змісту такого предметно-технологічного і соціального контексту майбутньої професійної діяльності у поєднанні з набуттям студентами особистого досвіду ії здійснення вимагає використання адекватних форм навчальної роботи за допомогою специфічних засобів і форм організації активного навчання студентів. Серед них А.О. Вербицький виокремлює три базові форми - навчальну діяльність академічного типу, квазіпрофесійну діяльність та навчально-професійну діяльність, а також вказує на множинність перехідних від однієї базової форми до іншої (Вербицький, 1987, с. 35). Сутність квазіпрофесійної діяльності студентів полягає у відтворенні в аудиторних умовах “науковою мовою” відповідними навчальними дисциплінами умов та динаміки виробництва, професійних відносин та дій фахівців, а серед іiі найбільш яскравих форм, що вдало моделюють предметний і соціальний зміст майбутньої професійної праці, автор виокремлює навчальні (ділові) ігри, тренінги, мікровикладання тощо. Вони у сукупній системній якості становлять технологію знаково-контекстного навчання. Щодо проміжних форм контекстного навчання, то, на думку автора, ними можуть виступати безліч конкретних технологій тактичного рівня, які також забезпечують “логіку” руху діяльності від навчальної до професійної, оскільки такий тип професійної освіти передбачає ії інтеграцію з різноманітними методологічними, стратегічними i, особливо, тактичними технологіями (Вербицький, 1987, с. 35; Вербицький, 1991, с. 62).

У технології контекстного навчання та організації квазіпрофесійної навчальної діяльності студентів вагоме місце посідає моделювальна практика, що полягає у заміщенні реального об'єкта професійної діяльності його модельним логіко-почуттєвим відтворенням у вигляді опису найбільш значущих властивостей. Відомості ж, отримані при вивченні такої імітаційної моделі, переносяться на розуміння реальних об'єктів пізнання (Вербицький, 1987, с. 76). Імітаційні навчальні моделі, за А. О. Вербицьким, передбачають “вихід” студента за межі текстових знакових систем з їх переважно вербалізованими засобами пізнання шляхом співвідношення цієї інформації з ситуаціями майбутньої професійної діяльності, а набуті знання перетворюються у смисли, що забезпечує особистісне включення студента у вирішення квазіпрофесійних завдань предметної галузі праці, яку він опановує. Поряд із застосуванням навчальної інформації у такий спосіб відбувається ії суб” єктивне “проживання” у формах професійної поведінки, а одиницею такої навчальної роботи виступає предметна дія, що забезпечує досягнення на іï основі практично корисного ефекту (Вербицький, 1991, с. 70). Використання імітаційних технологій навчання у вищій школі дозволяє уникати багатьох недоліків традиційного навчання, пов'язаних із пасивністю студентів та часто формальним характером їх знань внаслідок зайвої вербалізації навчального процесу, недостатнього його впливу на емоційно-образну, практико-перетворювальну сфери особистості майбутнього професіонала. Поряд із можливостями посилення індивідуалізації професійної підготовки імітаційні моделі сприяють і набуттю колективного досвіду розв'язання професійних проблем, здатності до колективної рефлексії, продуктивного професійного спілкування, трансформації засвоєних знань у внутрішній план дій (Стрельніков, 2002, с. 144-148).

Викладені положення та характеристики мета-технології контекстного навчання та імітаційного навчання як його похідної цілком відповідають особливостям підготовки освітянських кадрів до професійної творчості та майстерності, що передбачає оволодіння майбутніми педагогами в спеціально створених лабораторних умовах аудиторних практичних занять різноманітними моделями і техніками квазіпрофесійної педагогічної діяльності ще до iii безпосереднього виконання. Застосовуючи імітаційні технології вивчення педагогічних дисциплін дидаскалогічного спрямування доцільно спиратися на принципи імітаційного навчання, сформульовані В.Ю. Стрельніковим, а саме:

принцип проблемності, що полягає в організації групового обговорення можливих шляхів вирішення професійно-педагогічних ситуацій, їх аналізу, а не просто засвоєння “рецептурних” вказівок викладача щодо певних алгоритмів педагогічних дій;

принцип особистісної взаємодії - залучення кожного студента до активної діяльності, що запобігає їх байдужості та інфальтивності і сприяє виробленню системи моральних, інтелектуальних, соціальних і професійних якостей;

принцип єдності розвитку кожного студента і групи, що забезпечується “поліфонічністю” навчального спілкування, засвоєнням різних ролей і функцій, взаємостимулюванням і взаємоконтролем;

принцип самонавчання на основі рефлексії дозволяє орієнтуватися на індивідуальні запити на основі регулярної самооцінки і самоконтролю в різних професійних позиціях та усвідомлення використаних способів для отримання кінцевих результатів (Стрельніков, 2002, с. 16-148).

До особливого виду навчального імітаційного моделювання квазіпрофесійної діяльності студентів належить так зване ситуаційне навчання або “кейс-метод”, яке було започатковано у 50-ті рр. у західній бізнесовій, медичній, юридичній освіті та майже відразу почало активно використовуватися у підготовці вчителів. Відомий американський дослідник у галузі педагогічної освіти Л. Шульман обгрунтував потенційні можливості цього методу та рекомендував використовувати його при вивченні студентами загальних концепцій навчання i виховання, проблем моралі, етики і звичок педагогічного мислення ще до педагогічної практики в школі (Кошманова, 2000, с. 22-23). Популярність такої посткласичній технології, що полягає в організації аудиторної роботи студентів над спеціально створеними імітаційно-дидактичними моделями майбутньої професійної діяльності, зумовлена комплексом провідних ідей, а саме: студенти разом із викладачем розв'язують пізнавальну проблему, яка має кілька варіантів вирішення на відміну від академічної схеми надати єдино “правильні” раз і 
назавжди знання, уміння й навички; цій технології властивий демократичний характер отримання знань, коли викладач втрачає позицію “ментора", “начитувача” і перетворюється на організатора процесу співтворчості; поряд із засвоєнням знань студент виробляє професійні навички та набуває досвіду їх практичного застосування; за “законами жанру” та правилами цього методу виробляється імітаційна модель конкретної професійної ситуації, що може мати вигляд тексту, вивчатися студентами із залученням різноманітних джерел інформації для отримання комплексу знань та умінь для іiі вирішення, а потім детально обговорюватися на практичних заняттях, диспутах (Стрельніков, 2002, с. 90).

Ситуаційне навчання майбутніх педагогів у вітчизняній освітній традиції частіше використовується в дещо модифікованому вигляді та більш відоме під назвою задачної технології, що останнім часом набула поширення та визнання у сучасній теорії і практиці педагогічної освіти, про що свідчать численні видання різними авторами збірок педагогічних задач і ситуацій та методик їх розв’язання (Г.В. Нікішина, С.М. Глубокова, Л.О. Мільто, В.Л. Омельяненко, М.В. Даниленко, Л.І. Даниленко, Л.В. Кондрашова, Л.І. Рувінський та ін.). Задачний підхід до професійно-педагогічної підготовки вчителів випливає з науково-теоретичних уявлень про задачну природу $\mathrm{i}$ структуру педагогічної діяльності та її операційний характер, в яких практика підготовки вчителів виступає для викладачів процесом вирішення неперервного ряду педагогічних задач, що, на думку Ю.В. Сенька, досить осмислено в дидаскалогії (Сенько, 2000, с. 95). Тому дослідники вважають моделювання, вирішення, аналіз педагогічних задач і ситуацій ефективним засобом, умовою оволодіння студентами педагогічних навчальних закладів технологічною культурою педагогічної праці та оригінальним методом психолого-педагогічної підготовки (Кулюткін, \& Сухобська, 1981, с. 56). 3 позицій системного підходу задачна технологія організації професійнопедагогічної підготовки забезпечує ії цілісність, проблематизацію, технологічність завдяки дидактичній організації відтворення та імітації вироблення студентами педагогічних рішень за допомогою різноманітних алгоритмічних та квазіпрофесійних способів і прийомів (Сластьонін, \& Міщенко, 1991, с. 80-82); (Спірин, 1997, с. 56). При цьому, на думку Ю.М. Кулюткіна та Г.С.Сухобської, провідною метою розв'язання педагогічних задач у процесі підготовки вчителя виступає засвоєння студентами критеріїв оцінювання власних педагогічних рішень, принципів і правил такого “апарату” організації педагогічної діяльності (Кулюткін, \& Сухобська, 1981, с. 57).

Задачний підхід широко використовується у масовій практиці викладання дидаскалогічних дисциплін у педагогічних навчальних закладах, що підтверджується здійсненим аналізом навчальних програм і посібників 3 основ педагогічної майстерності (творчості), вступу до педагогічної професії (спеціальності), педагогічної майстерності викладача вищої школи тощо. Для цього залежно від теми добираються або створюються як типові, так і нестандартні педагогічні ситуації та задачі, які відображають різноманітні специфічні грані педагогічної праці та поведінки вчителя. Процес їх розв'язання органічно “вписується” в лекційні курси, семінари, лабораторні заняття в різноманітних “форматах - ілюстрацій до теоретичних положень, дискусійного обговорення та аналізу можливих підходів, самостійного проектування студентами педагогічних задач та способів здійснення раціональних педагогічних впливів, проведення театралізованих педагогічних ігор та вправ, інсценізації та “рольового” виконання проблематизованих педагогічних сюжетів, підготовки повномасштабних дидаскалогічних проектів тощо.

Програмними вимогами вивчення студентами бакалаврату Національного педагогічного університету імені М.П. Драгоманова навчального курсу з основ педагогічної творчості та майстерності передбачається висвітлення теорії педагогічних задач та технологічних засад їх розв'язання в лекційному курсі, проведенні спеціальних лабораторних занять за цією темою, а також фрагментарне використання задачного методу на практичних заняттях 3 інших тем, включення результатів індивідуального розв'язання кожним студентом педагогічної задачі до поточного й підсумкового контролю. Крім того, у нашому експериментальному досвіді використання задачного підходу як складової мета-технології контекстного навчання застосовувався і додатковий експериментальний фактор у вигляді гуманітарної версії задачної технології, запропонованої Ю.В. Сенько. Вона полягає у некласичному розумінні педагогічної задачі як гуманітарного феномена, відповідно до чого професійна педагогічна задача представляє породжену процесом професійної освіти модель реальної педагогічної ситуації, що має проблемний характер не лише для студента, а й для викладача, і створює в ході іï розв'язання умови для становлення професіоналізму та індивідуальності майбутнього фахівця (Сенько, 2000, с. 96). Гуманітарний смисл задачної технології, на думку автора, визначається тим, що викладачеві “дана” лише конкретна педагогічна ситуація, “всередині” якої він знаходиться сам, і яку слід перетворити на педагогічну задачу, виявити ії прихований смисл, сформулювати мету діяльності педагога як мисленнєву модель очікуваного результату, оцінити зв’язки між різними явищами. Гуманітарними ж координатами цього процесу виступають другодомінантність, діалогічність, рефлексивність, метафоричність, а їх ядром - стиль нового педагогічного мислення (там само, с. 97).

Серед різноманітних лабораторних практикумів з основ педагогічної творчості та майстерності спеціальні заняття та їх окремі фрагменти присвячуються навчанню студентів аналізувати педагогічні ситуації та вирішувати різноманітні педагогічні задачі, за допомогою оволодіння базовими алгоритмами їх розв'язання. На першому етапі організовується робота студентів у малих групах з текстами педагогічних ситуацій, проведення їх аналізу та постановки запитань рефлексивного типу і пошуку розгорнутих відповідей на них на зразок внутрішнього мовлення (що “дано” в ситуації і що б я зробив? (Я б діяв так...), тому що (мотиви моїх дій полягають у...), для чого? з якою метою? (я прагну досягти результату...), заради чого? (смисл мого рішення становить...), які можуть виникнути ускладнення та негативні наслідки? (я хвилююся через те, що може статися...) що нового в цьому рішенні? (воно відрізняється - не відрізняється від інших...). Крім того, студенти визначають критерії, що засвідчують оптимальність знайденого рішення, серед яких найчастіше називаються справедливість, виховний ефект педагогічних дій, культура поведінки, збереження гідності всіх учасників педагогічної взаємодії, педагогічний такт тощо. На другому етапі проводиться “захист” кожною мікрогрупою знайденого варіанта рішення та здійснюється їх обговорення у формі позиційної дискусії. Для цього широко використовується проведення 
ділової гри типу “педагогічного консиліуму”, що імітує педагогічну нараду, в якій беруть участь дійові особи ситуації та компетентні судді в образі уявних представників адміністрації закладу, шкільного психолога, членів батьківського комітету, можливо, учнів. Це стає найвищим щаблем рольової гри, оскільки способи дій будуються самою людиною, а не задаються ззовні, що дозволяє створювати діалог позицій і передбачає їх аргументацію 3 урахуванням різних поглядів. Використання прийому “зміни позицій” забезпечує вироблення кількох варіативних рішень, тим самим перешкоджає утвердженню догматичних установок та стереотипних педагогічних дій студентів, тому на завершенні практикуму вирішення педагогічних задач замість традиційного “підведення підсумків", “формулювання висновків” відбувається пошук відповідей на питання “чому мене навчила робота над цією ситуацією?”, “які вимоги вона висуває до педагога?”. На третьому етапі відбувається колективне складання умовного алгоритму процесу прийняття педагогічного рішення та розв’язання педагогічної задачі, а також висуваються вимоги до кожного 3 його етапів, що потім порівнюється 3 існуючими в науково-методичній літературі підходами до вирішення цієї проблеми.

Висновки. Таким чином, відрефлексовані евристичні можливості імітаційно-ситуаційного навчання засвідчують адекватність зазначеного технологічного інструментарію завданням поглиблення контекстної спрямованості підготовки майбутніх педагогів до професійної творчості та майстерності. Презентований експериментальний досвід оригінального використання імітаційно-ситуаційного навчання при викладанні курсів з основ педагогічної творчості та майстерності доводить його ефективність у засвоєнні студентами бакалаврату змісту дидаскалогічної освіти з позицій параметрів особистісності, проблемності, креативності, діалогічності, суб’єктності, рефлексивності, праксеологічності та вказує на необхідність подальшої інтеграції методів імітаційно-ситуаційного навчання майбутніх педагогів дисциплінам дидаскалогічного спрямування 3 іншими інноваційними типами і моделями вузівського навчання - проблемно-евристичним, інтерактивним, проектним, кооперативним та ін.

\section{Список використаних джерел}

Барбина, Е. С., Семиченко, В. А. (1996). Идеи интеграции, системности и ичелосности в теории и практике высшей школь. Киев: Полиграфкнига.

Вербицкий, А. А. (1987). Концепция знаково-контекстного обучения в вузе. Вопросы психологии, 5, 31-37.

Вербицкий, А. А. (1991). Активное обучение в высшей школе: контекстный подход. Москва: Высшая школа.

Кошманова, Т. С. (2000). “Кейс“-метод в педагогічній освіті США. Шлях освіти, 1, 22-24.

Кулюткин, Ю. Н., Сухобская, Г. С. (Ред.). (1981). Моделирование педагогических ситуаций: проблемы повымения качества и эффективности общепедагогической подготовки учителя. Москва: Педагогика.

Сенько, Ю. В. (2000). Гуманитарные основы педагогического образования. Москва: Академия.

Сластенин, В.А., Мищенко, А. И. (1991). Профессионально-педагогическая подготовка современного учителя. Педагогика, 10, 79-84.

Спирин, Л. Ф. (1997). Теория и технология решения педагогических задач. Москва: Российское педагогическое агенство.

Стрельніков, В. Ю. (2002). Педагогічні основи особистісного й професійного розвитку студентів засобами інновачійних технологій навчання. Полтава: РВВ ПУСКУ.

\section{References}

Barbina, E. S., Semichenko, V. A. (1996). Idei integratcii, sistemnosti i tcelosnosti v teorii i praktike vysshei shkoly [Ideas of integration, systemicity and integrity in the theory and practice of higher education]. Kiev: Poligrafkniga [in Russian].

Verbitckii, A. A. (1987). Kontceptciia znakovo-kontekstnogo obucheniia v vuze [The concept of sign-contextual education in high school]. Voprosy psikhologii [Psychology Issues], 5, 31-37 [in Russian].

Verbitckii, A. A. (1991). Aktivnoe obuchenie v vysshei shkole: kontekstnyi podkhod [Active Learning in Higher Education: A Contextual Approach]. Moskva: Vysshaia shkola [in Russian].

Koshmanova, T. S. (2000). "Keis“-metod v pedahohichnii osviti USA [Case Study Method in US Teacher Education]. Shliakh osvity [The path of education], 1, 22-24 [in Ukrainian].

Kuliutkin, Iu. N., Sukhobskaia, G. S. (Red.). (1981). Modelirovanie pedagogicheskikh situatcii: problemy povysheniia kachestva i effektivnosti obshchepedagogicheskoi podgotovki uchitelia [Modeling of pedagogical situations: problems of improving the quality and effectiveness of teacher training]. Moskva: Pedagogika [in Russian].

Senko, Iu. V. (2000). Gumanitarnye osnovy pedagogicheskogo obrazovaniia [Humanitarian foundations of teacher education]. Moskva: Akademiia [in Russian]. 
Slastenin, V. A., Mishchenko, A. I. (1991). Professionalno-pedagogicheskaia podgotovka sovremennogo uchitelia

[Professional and pedagogical training of a modern teacher]. Pedagogika [Pedagogy], 10, 79-84 [in Russian].

Spirin, L. F. (1997). Teoriia i tekhnologiia resheniia pedagogicheskikh zadach [Theory and technology of solving pedagogical problems]. Moskva: Rossiiskoe pedagogicheskoe agenstvo [in Russian].

Strelnikov, V. Yu. (2002). Pedahohichni osnovy osobystisnoho y profesiinoho rozvytku studentiv zasobamy innovatsiinykh tekhnolohii navchannia [Pedagogical bases of personal and professional development of students by means of innovative teaching technologies]. Poltava: RVV PUSKU [in Ukrainian].

\section{HUZII N.}

M. P. Dragomanov National Pedagogical University, Kyiv, Ukraine

\section{IMITATION-SITUATIONAL CASE STUDY WITHIN THE CONTEXT-ORIENTED SYSTEM OF EDUCATION OF FUTURE TEACHERS ON PROFESSIONAL CREATIVITY AND SKILLFULNESS}

The article presents the results of scientific analysis on evristic potential of imitation-situational case study as contemporary innovative method that facilitates the context-oriented education of future teachers for professional creativity and skillfulness.

The content of the article describes in details the phenomenon of dydascalogical trainings for teachers and other pedagogical staff in general as well as its special types study - namely the courses on basics of pedagogical creativity and skillfulness, their unique subject of study is defined, their importance of being the efficient method of professional education of the students and substantial factor for integration of professional training of future teachers and its completeness, and also the article proves the appropriateness of using non-standard innovative practice-oriented pedagogical methods for student' command on dydascalogical knowledge, in particular the imitation-situational training of the context type system of higher pedagogical education.

The article proves that the dydactical potential for meta-methods of context (figurative-context) training is explained through the options of facilitating the change of activities of future professionals from educational process to professional tasks, transformation of the student' knowledge from the study component to the professional feedback tools, changing their motivation from study to professional type. The key dydascological issue of educator' task with the student changes from "set of information" as system of figures to "problem solution case" of professional activities representing all related subject matter and social discrepancies and conflict points. The modeling and comprehension of essence of the said subject methods and the social context of future professional activities along with gaining personal experience is provided by pedagogical framework of professional-like pedagogical activities of the students with extensive engagement of imitational educational models and methods of situational study.

The results of experiments on specific use of imitation-situational study for education on the basics of pedagogical creativity and skillfulness delivered in the article proved the efficiency of such experimental methods for study on the content of dydascological training for master degree students and their respective training on professional creativity and skillfulness.

Key words: context education; imitation-situational education; dydascalogical education; pedagogical skillfulness; pedagogical creativity

Стаття надійшла до редакції 10.03.2019 р. 